\title{
How does diet influence the reproductive seasonality of tropical freshwater fish? A case study of a characin in a tropical mountain river
}

\author{
Tania M. Ballesteros ${ }^{1}$, Mauricio Torres-Mejia ${ }^{2,3}$ and Martha P. Ramírez-Pinilla ${ }^{1,3}$
}

Seasonal breeding of tropical freshwater fish may be synchronized with periods of high food consumption. We explored this hypothesis by studying the relationship between diet and reproductive activity of Creagrutus guanes (Teleostei, Characidae). Our results showed that $C$. guanes had a generalist and omnivorous diet dominated by aquatic insects (mainly Diptera larvae) and seeds. Creagrutus guanes did not show intersexual or ontogenetic variation in diet. Peaks of feeding activity during rainy months were not synchronized with breeding in dry months. Our results do not support the hypothesis that the reproductive season has to be synchronized with high food consumption. We discussed the hypothesis fat reserves may be an important factor for the desynchronization of peaks of feeding and reproduction as explanation of seasonal breeding of this species.

A reprodução sazonal de peixes tropicais de água doce pode estar sincronizada com períodos de alto consumo de alimento. Nós examinamos esta hipótese estudando a relação entre dieta e atividade reprodutiva de Creagrutus guanes (Teleostei, Characidae). Nossos resultados mostraram que C. guanes teve uma dieta generalista e onívora, com predominância de insetos aquáticos (principalmente larva de Diptera) e sementes. Creagrutus guanes não apresentou variação intersexual ou ontogenética na dieta. Picos de atividade alimentar durante os meses chuvosos não foram sincronizados com atividade reprodutiva nos meses secos. Nossos resultados não sustentam a hipótese de que a estação reprodutiva está sincronizada com o consumo elevado de alimento. A reserva de gordura pode ser um fator importante para a dessincronização de picos de alimentação e reprodução (a reserva de gordura pode influenciar a ausência de sincronia entre os picos de alimentação e reprodução). São apresentadas hipóteses alternativas para a explicação de desova sazonal da espécie.

Key words: Feeding ecology, Phenology, Characidae, Fat reserves, Breeding, Creagrutus guanes.

\section{Introduction}

Whereas reproductive seasonality of temperate fish is determined mostly by temperature, tropical freshwater fish are conditioned by hydrology (Wootton, 1998). Most tropical freshwater fish breed during the rainy season (Kramer, 1978; Munro, 1990; Vazzoler \& Menezes, 1992; Jiménez-Badillo \& Nepita-Villanueva, 2000; Alkins-Koo, 2000); however, a few breed during the dry season (Kramer, 1978; Wang et al., 1995; Pusey et al., 2002; Torres-Mejia \& Ramírez-Pinilla, 2008), or throughout the year (Kramer, 1978; Alkins-Koo, 2000). Interspecific variation in reproductive seasonality has been associated with several factors, such as availability of nursery areas (Rinne \& Wanjala, 1983), availability of food for adults or juveniles (Lake, 1967; Kramer, 1978), competition for breeding sites, and phylogenetic inertia (Kramer, 1978). In this study we explored the hypothesis that in tropical freshwater fish the hydrological cycle indirectly affects reproductive seasonality through diet.

Most studies on the diet of tropical freshwater fish have focused on the comparison between feeding and hydrological cycle (Prejs \& Prejs, 1987; Esteves \& Pinto Lobo, 2001; de Alvarenga et al., 2006), but there are few analyses that have focused on the interaction between feeding and reproductive seasonality. It has been shown that many fish totally or partially shift their diets across seasons (Prejs \& Prejs, 1987; Mazzoni \& Rezende, 2003), and the highest feeding activity usually occurs during the rainy seasons when the availability of prey is relatively higher (Prejs \& Prejs, 1987). Many tropical freshwater fish reproduce during or after peak food availability and consumption (Rinne \& Wanjala, 1983; Esteves \& PintoLobo, 2001; de Alvarenga et al., 2006). Others can diminish or

\footnotetext{
${ }^{1}$ Laboratorio de Biología Reproductiva de Vertebrados, Universidad Industrial de Santander, A.A. 678, Bucaramanga, Colombia. marceballesteros10@gmail.com

${ }^{2}$ Department of Biology, University of California, Riverside, California, 92521, USA. rtorr006@ucr.edu

${ }^{3}$ Grupo de Estudios en Biodiversidad, Universidad Industrial de Santander, Colombia. mpramir@uis.edu.co
} 
even cease food ingestion during the reproductive season (Ikomi, 1996; Santamaría-Miranda et al., 2005). Besides quantity, the quality of food may also be related to reproduction. The high nutrient content from some food types may play a role in gonadal maturation trough its contribution in the store of fat reserves (e.g., Brooks et al., 1997). This wide range of scenarios make more research necessary to understand the role of diet in the reproductive seasonality of tropical fish, and the influence of the hydrological cycle on both diet and reproduction.

In this study we analyzed the influence of feeding ecology on the reproductive seasonality of Creagrutus guanes in a tropical mountain river. Specifically, we assessed the relationship between diet and the hydrological cycle by analyzing the trophic ecology of $C$. guanes throughout an annual cycle. We determined the relationship between diet and reproductive activity either by comparing these variables directly, or indirectly by comparing both with the hydrological cycle. Additionally, we examined intersexual and ontogenetic differences in diet.

\section{Material and Methods}

\section{Species and site study}

Creagrutus guanes is a small fish (maximum SL $=77 \mathrm{~mm}$ ) that inhabits slow-flowing areas of mountain rivers of the río Magdalena basin, Colombia (Torres-Mejia \& Vari, 2005). It breeds seasonally during dry months, and stores fat in response to rainfalls, presumably to invest it later in reproduction during dry periods (Torres-Mejia \& RamírezPinilla, 2008).

For this study we studied the same specimens used for a previous analysis of reproductive seasonality of the species (Torres-Mejia \& Ramírez-Pinilla, 2008). Specimens were collected at río Fonce and $500 \mathrm{~m}$ upstream from the mouth of one of its tributaries, the río Mogoticos (6 $6^{\circ} 25^{\prime}-6^{\circ} 31^{\prime} \mathrm{N} 73^{\circ} 7^{\prime}$ $73^{\circ} 9^{\prime} \mathrm{W}$, between 1100 and $1350 \mathrm{~m}$ of altitude), between the towns of San Gil and Charalá, Santander, Colombia. Río Fonce is part of the río Magdalena system and drains a region of the west side of the Andean Cordillera Oriental of Colombia. Rainfall follows a bimodal seasonal pattern that is characterized by a first rainy season from April to May, a short rainfall decrease from June to August, a second rainy season from September to November, and a long dry season from December to March. Since the pattern of flow was similar to the rainfall pattern (Torres-Mejia \& Ramírez-Pinilla, 2008), we used the rain pattern as an indicator of the hydrological cycle.

\section{Field and laboratory procedures}

From $11 / 2003$ to $11 / 2004$ we collected monthly samples of 20-30 fish longer than $20 \mathrm{~mm}$ SL. The capture methods implemented were cast nets, dip nets, seines, and hooks with worms as bait. Specimens were sacrificed by immersion in an overdosed solution of anesthetic. Fish were fixed in buffered formalin (10\%), transferred to ethanol (70\%) 15 to 30 days later, and deposited at the ichthyological collection of
Universidad Industrial de Santander, Colombia (UIS-T, see the list of catalog numbers in Material Examined below).

Digestive tracts were obtained from dissected specimens. Stomach and intestine weights $( \pm 0.001 \mathrm{~g})$ and intestine length $( \pm 0.02 \mathrm{~mm})$ were recorded for each specimen. Analysis of diet was based on stomach and intestine contents. Since the results of stomach-only and stomach and intestine content analyses were equivalent, we report here only the results of the latter. We measured the total prey volume in sized graduated cylinders by water displacement (Winemiller, 1990) for each individual. Prey types were separated, counted, and identified to the lowest possible taxonomic category (see Table 1 ). Based on known total prey volume (100\%), we visually estimated the percentage of each prey category, and then calculated the volume of each prey category. All visual estimates were made by the same individual. The digestive contents were differentiated into allochthonous (terrestrial) and autochthonous (aquatic) items. Data on sex and reproductive stages were obtained from Torres-Mejia \& Ramírez-Pinilla (2008), who classified specimens using macroscopic observations and histology. We compared the qualitative observations of the diet type with gut length by measuring the relative gut length (intestine length/standard length) and Zihler's Index (ZI = intestine length/(10 x body mass $^{1 / 3}$ ) Kramer \& Bryant, 1995).

\section{Diet analysis}

We used the Index of Relative Importance (IRI) to indicate the importance of each prey category (Pinkas et al., 1971). IRI was calculated as IRI $=\% F_{j}\left(\% N_{j}+\% V_{j}\right)$, where $j$ is each prey category, $\%_{\mathrm{j}}$ is the occurrence proportion (i.e., the proportion of guts containing each $j$ item), $\% \mathrm{~N}_{\mathrm{j}}$ is the proportion of the number of $j$ items in all guts, and $\% \mathrm{~V}_{j}$ is the proportion of the volume of $j$ items in all guts. To compare IRIvalues we used a relative value of IRI $\left(\% I_{R}=100\left(\right.\right.$ IRI $\left._{j} / \Sigma I_{\mathrm{j} I}\right)$, where $n$ is the number of total prey types).

We first explored ontogenetic and intersexual differences in diet. To examine ontogenetic differences, data from each sex were subdivided by size in categories of $10 \mathrm{~mm}$ SL. Differences in prey consumed among these size categories were tested with One-way Analyses of similarities (ANOSIM), and visualized with Non-metric Multi-Dimensional Scaling ordination (NMDS). ANOSIM is a non-parametric alternative to ANOVA. NMDS is a non-parametric ordination technique that condenses similarities between different samples in a small number of dimensions summarized in a scatterplot that places similar samples closer. Both methods use a Bray-Curtis similarity matrix (Clarke, 1993; Clarke \& Warwick, 1994), in this case composed with the IRI values of each prey category. NMDS and ANOSIM were conducted in PAST, v.1.85 (Hammer et al., 2001). The degree of overlap between different pairs of size categories was quantified with the niche overlap coefficient of Schoener $\left[\mathrm{S}=1-0.5\left(\Sigma \mathrm{P}_{\mathrm{xi}}-\mathrm{P}_{\mathrm{yi}}\right)\right]$, where $\mathrm{P}_{\mathrm{xi}}$ and $\mathrm{P}_{\mathrm{yi}}$ are the proportions of occurrence of each prey category $i$, in each pair of size category $(x, y)$ (Schoener, 1970). The degree of overlap was categorized as low $(<33.3 \%)$, moderate (33.3 - 
66.6\%), or high (> 66.6\%) (Schoener, 1970). The degree of variation in prey consumption for each size category was quantified with the trophic niche breadth index $\left(B_{A}\right)$ using Levins ' standardized formula: $\left.B_{A}=\left[\left(1 / \Sigma \mathrm{pi}^{2}\right)-1\right) /(\mathrm{n}-1)\right]$, where $p_{i}$ is the proportion of occurrence of each prey category and $n$ is the number of prey items consumed (Hurlbert, 1978). $B_{A}$ ranges from 0 to 1 , with values near zero indicating that only one or few prey types were consumed in high proportion or many prey types were used in low proportions, and values near one indicating that all prey were consumed in equal proportion. Differences in niche breadth among size categories were examined with G-tests. In addition to analyzing the variation in the type of prey consumed, we also analyzed the ontogenetic variation in the amount of prey consumed. Simple regressions with fish size (independent variable) and amount of food ingested (total prey volume and total prey number) were calculated after excluding individuals with empty guts and missing data. Finally, we also analyzed intersexual variation in diet by pooling all individuals from same sex and comparing the two sexes using NMDS and ANOSIM as explained above.

Second, we analyzed several aspects of annual variation in diet. Since our results showed that there was no ontogenetic or intersexual variation in diet, for subsequent analyses all individuals were pooled. Fish from June and July (both dry months) were also pooled to increase the number of observations in that group. To determine whether $C$. guanes varies its diet seasonally, we tested for variation in prey items consumed between seasons, which were defined as wet (April-May, September-November) or dry (December-March, June-August). Seasonal differences in diet were tested with ANOSIM, and visualized with NMDS. Following the ANOSIM global test, post-hoc tests were done using Similarity Percentage analysis (SIMPER) (Clarke \& Warwick, 1994), which allows the determination of which prey types were the most responsible for significant differences found between samples (data of each sex or one month). To determine seasonal variation in the amount of prey consumed we used ANCOVA, with (log-transformed) total prey volume as the dependent variable, standard length as the covariate, and season as the factor. The degree of diet overlap among seasons was calculated with Schoener's Coefficient, and the seasonal variation in the spectrum of prey species consumed was quantified with the Trophic Niche Breadth index $\left(B_{A}\right)$, using G-tests to examine differences in niche breadth among seasons. As a follow up question, we analyzed whether observed diet variation through time was related to rainfall. To do so we used Pearson correlations among rainfall with total prey volume, and the volume of the most consumed prey items (seeds, Diptera larvae). Assumptions of normality, linearity, and homogeneity of variance were fulfilled after logtransforming the data.

Third, we assessed some aspects of the interaction between diet and reproduction. These analyses were restricted to females because few males were collected. We used Pearson correlations to examine the degree of association between total prey volume, volume of the most important prey types (Diptera larvae and seeds), factors associated with the reproduction (gonad and fat weight, obtained from TorresMejia \& Ramírez-Pinilla, 2008), and rainfall. Since fat reserves influence gonadal maturation (Blanco-Parra \& BejaranoRodríguez, 2006; Ribeiro et al., 2007), we tested whether the volume of the most abundant prey (Diptera and seeds) influence fat weight. We explored the possibility that there was a lag in the correlation among total prey volume, gonad weight, and fat weight in month $x$ with each relevant explanatory variable at the same month $(x)$, one months before $(x-1)$, two months before $(x-2)$, one month later $(x+1)$, and two months later $(x+2)$. A degree of freedom (i.e., the unmatched observations at the tail of each series) was lost every time a month was lagged. To correct for the repeated use of same data for several correlations, we used the false discovery rate control of Verhoeven et al. (2005), which is an alternative to Bonferroni correction that is less prone to be too conservative and commit Type II errors (i.e. not recognizing significant effects).

\section{Results}

We analyzed 215 digestive tracts of adults and juveniles of $C$. guanes (34 males, 126 females, and 55 juveniles), finding 989 prey from 11 taxa (Table 1). Only four specimens had empty guts, and they were excluded from further analyses. The diet of C. guanes was omnivorous, composed mostly of aquatic insects $(\% \mathrm{IRI}=57.71 \%)$ and seeds $(\% \mathrm{IRI}=37.86 \%)$ (Table 1). Diptera larvae was the most common insect prey $(\%$ IRI $=29.52 \%)$, represented largely by the family Chironomidae. The importance of the other aquatic orders (Ephemeroptera, Trichoptera, Coleoptera, Odonata, and Hemiptera) was minimal (\%IRI $<0.80 \%)$. Terrestrial insects were rare (Formicidae \%IRI = 3.55\%). Dietary niche breadth of $C$. guanes was small $\left(B_{A}=0.07\right)$, indicating the consumption of few prey types. The average Relative Gut Length (0.7632) and Zihler's (3.42) index were in the range of omnivorous fishes (Kramer \& Bryant, 1995), in agreement with stomach content analysis.

The diet of $C$. guanes varied little among ontogenetic categories and between sexes (Fig. 1). The diet of both sexes was indistinguishable (ANOSIM, $R=-0.007, P=0.43$ ). There were no significant differences among size categories in prey items consumed (ANOSIM, $R=-0.08, P=0.65$ ), nor niche breadth $\left(G_{0.05,1}=0.40, P>0.05\right)$. The overlap of diet between all pairs of size categories was always high (range of percentage overlap observed was between $70 \%$ and 95\%). The only ontogenetic change observed in diet were that the average prey volume increased with fish body size $\left(r^{2}=0.72\right.$, $P=0.0001, N=193$ ), and that there was a negative relationship between number of prey and fish body size $\left(r^{2}=0.04, P=\right.$ $0.0001, N=160$ ). Therefore, $C$. guanes consumed the same types of prey along its ontogeny, but fewer and larger prey were consumed by larger fish.

Creagrutus guanes consumed the same prey types 
Table 1. Diet of Creagrutus guanes. $\mathrm{N}=$ number of each prey item, $\% \mathrm{~N}=$ Percentage of $\mathrm{N}, \mathrm{F}=$ number of guts containing each prey item, \%F = Percentage of F, V = Volume of each prey item, \%V = Percentage of V, IRI = Index of Relative Importance.

\begin{tabular}{lcccccccc}
\hline \multicolumn{1}{c}{ Prey type } & $\mathrm{N}$ & $\% \mathrm{~N}$ & $\mathrm{~F}$ & $\% \mathrm{~F}$ & $\mathrm{~V}$ & $\% \mathrm{~V}$ & IRI & \%IRI \\
\hline Seeds & 485 & 49 & 101 & 46.97 & 1.93 & 35.21 & 3955.34 & 37.86 \\
Filamentous algae & & & 12 & 5.58 & & & & \\
Terrestrial arthropodos & 103 & 10.41 & 55 & 25.58 & 0.41 & 7.62 & 461.20 & 4.41 \\
$\quad$ Aranae & 1 & 0.10 & 1 & 0.46 & 0.02 & 0.25 & 0.16 & 0.0015 \\
Terrestrial insects & 97 & 9.80 & 55 & 25.58 & 0.35 & 6.47 & 416.18 & 3.98 \\
$\quad$ Formicidae & 92 & 9.30 & 54 & 25.11 & 0.30 & 5.47 & 370.87 & 3.55 \\
$\quad$ Adult Diptera & 3 & 0.30 & 2 & 0.90 & 0.01 & 0.13 & 0.38 & 0.0036 \\
Aquatic insects & 401 & 40.54 & 133 & 61.86 & 3.12 & 56.92 & 6028.87 & 57.71 \\
$\quad$ Diptera & 325 & 38.86 & 101 & 46.97 & 1.47 & 26.81 & 3084.51 & 29.52 \\
$\quad$ Chironomidae & 292 & 29.52 & 91 & 42.32 & 0.87 & 15.90 & 1922.17 & 18.40 \\
$\quad$ Ephemeroptera & 12 & 1.21 & 8 & 3.72 & 0.12 & 2.22 & 12.77 & 0.12 \\
$\quad$ Trichoptera & 19 & 1.92 & 13 & 6.04 & 0.18 & 3.42 & 32.26 & 0.30 \\
$\quad$ Coleoptera & 36 & 3.64 & 23 & 10.69 & 0.18 & 3.41 & 75.36 & 0.72 \\
$\quad$ Hemiptera & 3 & 0.30 & 3 & 1.39 & 0.02 & 0.31 & 0.85 & 0.0081 \\
$\quad$ Odonata & 6 & 0.60 & 6 & 2.79 & 1.16 & 21.16 & 60.72 & 0.58 \\
Total & 989 & & 215 & & 5.48 & & 10445.41 & \\
\hline
\end{tabular}

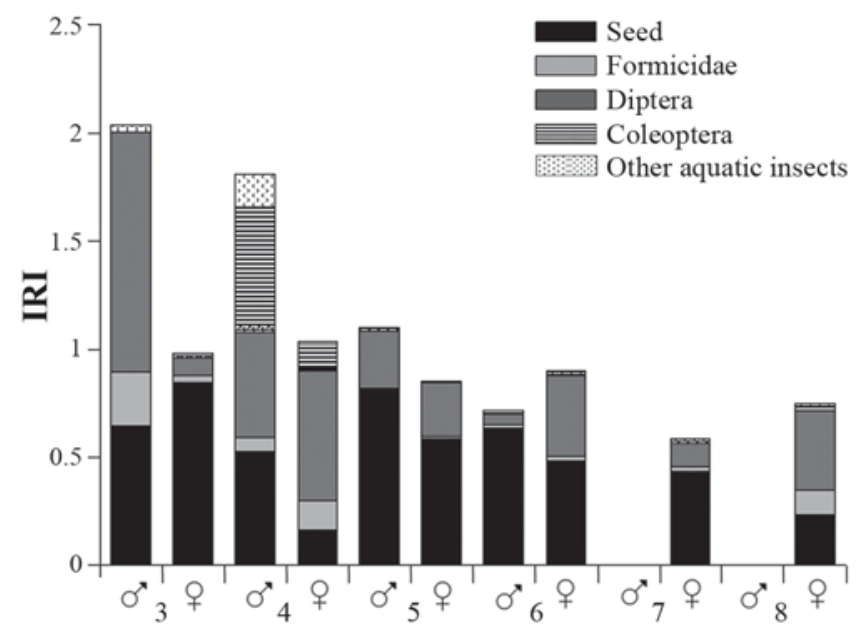

Size class

Fig. 1. Ontogenetic and intersexual variation in the diet of Creagrutus guanes. Size classes correspond to standard length ranges: $3=21-30 \mathrm{~mm} ; 4=31-40 \mathrm{~mm} ; 5=41-50 \mathrm{~mm} ; 6=$ $51-60 \mathrm{~mm} ; 7=61-70 \mathrm{~mm} ; 8=71-80 \mathrm{~mm}$.

throughout the year, but the relative importance of different prey consumed varied among seasons (Fig. 2). The ordination of the contributions of the different dietary categories showed two groups: rainy month samples were more concentrated at the bottom-left area of the plot, whereas samples from dry months occupied the top-right area (Fig. 3). The moderate stress coefficient of 0.1 indicated that the resulting ordination plot was reliable (Clarke \& Gorley, 2001). There were significant differences between rainy and dry season samples $(R=0.22$, $P=0.02)$. SIMPER showed that most of dissimilarity among samples (87\%) was produced by seed (55\%) and Diptera larvae (31\%) consumption (Table 2). Seeds were more consumed during rainy season, and Diptera larvae increased during dry season. Besides, total prey volume was higher during rainy season $\left(F_{0.05(1) 1,147}=138.03, P=0.0001\right)$. Rainfall was correlated with consumption of seeds $\left(r^{2}=0.46, P=0.015, N=12\right)$, but

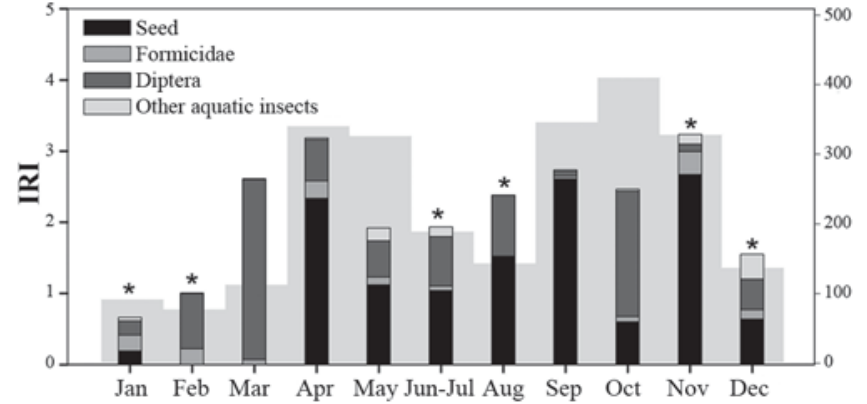

Fig. 2. Monthly variation of prey types-IRI values. Rainfall follows a bimodal seasonal pattern (shadow on background). The asterisks show the months in which reproduction occurs.

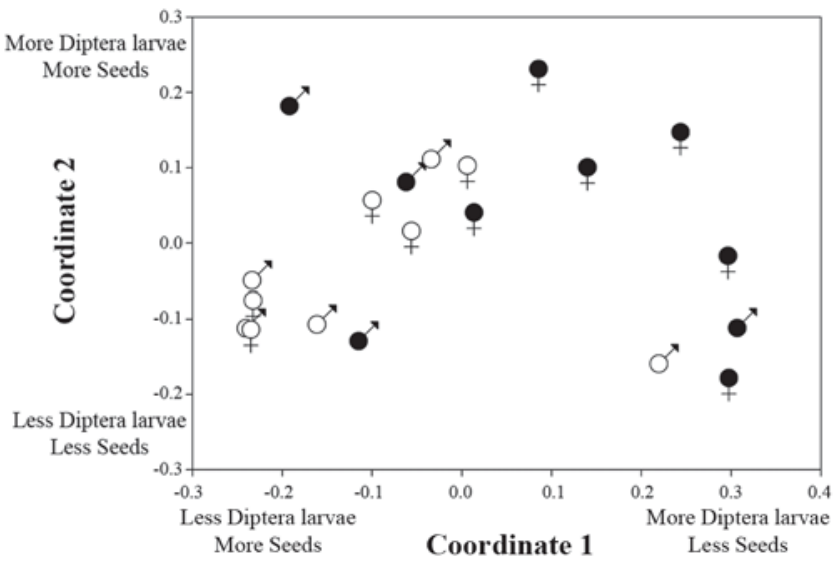

Fig. 3. Non-Metric Multi-Dimensional Scaling Ordination (NMDS) of monthly variations of the diet with respect to sex. Stress $=0.10$. Filled symbols are the dry months.

not with consumption of Diptera larvae, or ants, or with total prey consumption. The overlap of diet between rainy and dry season was high ( $\mathrm{S}=85.25 \%$ ), indicating that the fish ate similar prey among seasons. Similarly, dietary niche breadth 
Table 2. Contributions of different diet items to the dissimilarity between dry and wet season diets based upon NMDS plot (Fig. 2). Average dissimilarity between groups $=87 \%$ (from SIMPER).

\begin{tabular}{lcccc}
\hline \multicolumn{1}{c}{ Diet items } & $\begin{array}{c}\text { Mean } \\
\text { Abundance } \\
\text { (wet) }\end{array}$ & $\begin{array}{c}\text { Mean } \\
\text { Abundance } \\
\text { (dry) }\end{array}$ & $\begin{array}{c}\text { Mean } \\
\text { dissimilarity }\end{array}$ & $\begin{array}{c}\text { Percent } \\
\text { contribution }\end{array}$ \\
\hline Seed & 0.937 & 0.34 & 31.52 & 54.51 \\
Diptera & 0.303 & 0.549 & 18.77 & 86.97 \\
Formicidae & 0.0746 & 0.0702 & 3.935 & 93.77 \\
Coleoptera & 0.026 & 0.0226 & 1.637 & 96.60 \\
Odonata & 0.00283 & 0.02 & 1.037 & 98.39 \\
Trichoptera & 0.00553 & 0.00815 & 0.5133 & 99.28 \\
Ephemeroptera & 0.0048 & 0.00095 & 0.2169 & 99.65 \\
Hemiptera & 0 & 0.00388 & 0.1996 & 100.00 \\
\hline
\end{tabular}

was similar between seasons (rainy season $B_{A}=0.04$, dry season $B_{A}=0.11 ; G_{0.05,1}=0.04, P>0.05$ ).

The results of lagged correlations were inconclusive. Total volume of all prey, and volume of Diptera larvae were not related with rainfall, gonad weight, or fat weight (Table 3). On the other hand, the volume of seeds was correlated with rainfall and fat weight $(R=0.70, n=11, P=0.016)$. Interestingly, the volume of seeds was not related with gonadal weight during the same month, but high gonadal weights were observed two months after high seed consumption $(R=0.66$, $n=9, P=0.05$ ), and low seed consumption was observed one month after females had high gonadal weights $(R=-0.70, n=$ $10, P=0.024$ ) (Table 3). However, these results lost statistical significance after correcting for multiple testing.

\section{Discussion}

Our observations indicate that for C. guanes reproduction (Torres-Mejia \& Ramírez-Pinilla, 2008) was not synchronized with current food consumption. In fact, the food item most consumed by $C$. guanes, seeds, was more frequently found in specimens collected during the rainy season, whereas these fish breed during the dry season. This evidence does not support the hypothesis (Kramer, 1978) that the reproductive season of tropical freshwater fish would be synchronized with high food consumption. In the next paragraphs we discuss this result and other hypotheses for the seasonal reproductive patterns of tropical freshwater fish.

The diet of C. guanes is not unusual among tropical freshwater fish. Creagrutus guanes is an omnivore and generalist species that consumed high proportion of benthic fauna (mostly Diptera larvae), and allochtonous matter (mostly seeds). The diet of $C$. guanes is similar to the diet of other members of the genus Creagrutus (Ortaz, 1992, 2001; RománValencia, 1998), and other members of the order Characiformes, even from different habitats such as floodplain rivers (Ortaz, 1992; Esteves \& Galletti Jr., 1995; Ortaz, 2001; Vilella et al., 2002; Barreto \& Aranha, 2006). We conclude that the diet of C. guanes is not a rare case, but instead may represent the diet of many tropical freshwater fish.

The absence of variation in the type of prey along the ontogeny was an unusual aspect of the diet of C. guanes. Many tropical fish present ontogenetic diet shift of the type of prey consumed (Mérigoux, 1998) associated mainly with change in habitat use (Barros, 2004; Santamaría-Miranda et al., 2005) or related to morphological changes that lead to shifts in prey selection and capture (Araújo et al., 2005). It is unknown whether $C$. guanes shows morphological and habitat use variations. We speculate that $C$. guanes has a diet shift, but it occurred at a body size smaller than our range of sampling. Another interesting result was that in $C$. guanes food consumption was not dependent on sex. Probably, males and females did not show spatial or seasonal habitat segregation, and adult males continued feeding in the same areas occupied by females, even during the breeding season.

Our analyses pointed at a seasonal variation in consumption of the main prey types (seeds and diptera larvae), except for the lagged correlations, which lost statistical significance after correcting for multiple testing. That loss could be the result of a reduction of statistical power after the correction, and perhaps future studies with extended sampling periods would be able to corroborate the patterns observed. These patterns agree with each other, and show that $C$. guanes consumed more seeds during the rainy season and these seeds seem to contribute to the concurrent fat storage. In fact, seed consumption and fat storage were not related with immediate

Table 3. $R$-values of lagged correlations. Monthly mean volumes of all prey, seeds and Diptera larvae were lagged and compared against mean monthly values of rainfall and fat and gonad weights. Comparisons were performed by lagging one or two months backward and forward, and without lagging. ${ }^{*} P<0.05$ without adjusting nominal $P$-values for multiple testing. No correlation was significant after the adjustment.

\begin{tabular}{lcccccc}
\hline Fixed Variable & Lagged Variable (volume) & Month - 2 & Month - 1 & Same month & Month +1 & Month +2 \\
\hline Rainfall & \multirow{3}{*}{ Total prey } & 0.03 & 0.13 & 0.28 & -0.15 & -0.44 \\
Fat & & 0.26 & -0.15 & 0.31 & -0.43 & -0.32 \\
Gonad & \multirow{2}{*}{ Seed } & 0.33 & 0.03 & -0.16 & -0.52 & 0.33 \\
\hline Rainfall & & -0.29 & 0.05 & $0.70^{*}$ & 0.42 & $<0.01$ \\
Fat & & 0.48 & 0.23 & $0.70^{*}$ & -0.14 & -0.35 \\
Gonad & \multirow{2}{*}{ Diptera } & $0.66^{*}$ & 0.36 & 0.00 & $-0.70^{*}$ & 0.14 \\
\hline Rainfall & & -0.41 & 0.16 & -0.51 & -0.57 & -0.31 \\
Fat & & -0.31 & -0.31 & -0.48 & -0.18 & 0.17 \\
Gonad & & -0.39 & -0.16 & 0.38 & 0.14 \\
\hline
\end{tabular}


gonad weight, but with gonad weight two months later.

The seasonal patters of consumption of the main prey types (seeds and Diptera larvae) were likely a product of their availability into the river. It has been proposed that the seasonal changes in diet composition partly reflect the seasonal changes of food resources (Xie et al., 2000). Many species show seasonality in food uptake related to hydrological cycle (Esteves \& Galleti Jr., 1995; González \& Oyarzún, 2003; Balcome et al., 2005), what may also be the case of two of the types of food items most consumed by $C$. guanes. During the rainy seasons seeds are more abundant and available in the stream (Lemus-Jiménez \& Ramírez, 2002; Ponce-Calderón, 2002), and coincidentally the rainy season was the period when $C$. guanes had the highest ingestion of seed. The highest abundance of some species of Diptera (Velásquez de Ríos et al., 2004) occurs at the transition period between rainy-dry seasons, also the period of greatest ingestion of Diptera larvae by C. guanes. In the habitats of many temperate and tropical fishes the timing of the allochthonous food input coincides with a period of reduced availability of aquatic prey (Garman, 1991). That also seems to be the case for $C$. guanes, whose diet showed that the ingestion of seeds was concomitant with a decline in ingest of Diptera larvae. In general, it seems that $C$. guanes presented differential usage of resources, taking advantage of the temporal variation of allochthonous (higher during rainy months) and autochthonous matter (higher during dry months).

Despite the dramatic difference in flooding pattern between upland and lowland rivers (Chapman \& Kramer, 1991), flooding after rainfalls may increase allochtonous materials in both types of systems. In many floodplain rivers the rainfall increases the river discharge and brings allochthonous matter into the river (Castillo-Rivera et al., 1994), increasing the spectrum of available prey. A similar trend may occur in mountain rivers, where floods commonly drive terrestrial organisms to the water, some who use floods for dispersal (Friedman \& Auble, 2000), and other who are catastrophically dragged (animals: Garman, 1991; plants: Castillo-Rivera et al., 1994; Swanson et al., 1998). Contrary to the considerable attention that the relationship of floods in lowland rivers and allochthonous food availability for fishes (e.g. Goulding, 1980), such relationship has been rarely investigated for upland rivers (see Winemiller, 1990 for an exception).

The evidence that we collected in this analysis does not support Kramer's hypothesis that the reproductive season is synchronized with food consumption (Kramer, 1978). Creagrutus guanes breeds later during dry months, but consumed the greatest volume of food dominated by seeds during the rainy months. The peaks of availability of different sorts of foods were not synchronized with the breeding seasons. This asynchrony is not unusual among tropical fish (Kramer, 1978; Esteves \& Pinto Lobo, 2001; de Alvarenga et al., 2006), either from floodplain rivers (e.g. Bryconamericus emperador and Brycon petrosus, Kramer, 1978; Salminus brasiliensis (as Salminus maxillosus), Esteves \& Pinto Lobo, 2001; Curimatella lepidura, de Alvarenga et al., 2006) or from mountain rivers (e.g. Creagrutus brevipinnis, Román-Valencia, 1998).

Fat reserves may have been the crucial factor in the desynchronization of feeding and reproductive peaks in $C$. guanes. During rainy months, the highest consumption of seeds coincided with the maximum fat weight of the females. Possibly, the nutrients from seeds were responsible for the highest proportion of fat reserves. The observation of females with the highest total prey volume during heavy rains, the increase of fat weight soon after heavy rains and subsequent increase of gonad weight on dry months indicated that resources are being stored during rainy months to be invested later in reproduction (Esteves \& Pinto Lobo, 2001; TorresMejia \& Ramírez-Pinilla, 2008). In some tropical fish, the capacity to build up fat reserves allows the time of spawning to be independent of the time of food abundance (Kramer, 1978; de Avarenga et al., 2006). There is a need for more studies that assess the role of fat reserves in the reproduction of tropical fish.

Other factors have been hypothesized to influence reproductive seasonality of tropical freshwater fish. These factors include evolutionary history, availability of nursery areas (Rinne \& Wanjala, 1983), interspecific competition for food among juveniles, species social system (Kramer, 1978), and habitat stability (Humphries et al., 1999). For explaining the reproductive pattern of $C$. guanes we lean towards the hypothesis that a more stable habitat (no flash floods) during dry seasons (Humphries et al., 1999) could favor the survival of offspring and female recovery. Indirectly, the absence of floods during dry season may favor fish larvae by allowing the growth of small aquatic organisms (e.g. zooplankton, macroinvertebrates) (Lytle \& Poff, 2004) which usually are consumed by fish larvae. In mountain rivers reproduction during dry months is more common than in lowlands (TorresMejia \& Ramírez-Pinilla, 2008). Possibly, the intensity and predictability of the flow regimes in mountain rivers may have lead to life history adaptations (Lytle \& Poff, 2004), favoring breeding during the low-flow season.

Further analyses of the factors associated with the reproductive pattern of tropical fish are needed. Due to variations in the flow regimes and life history adaptations of fish, the analyses should involve floodplain, lowland, and mountain rivers. More research is necessary to assess the synchrony of reproductive seasonality with food consumption and food availability, fat storage, and the influence of the hydrological cycle on them. For a greater understanding of the reproductive timing of tropical fish, additional studies of the importance of the fat reserves as intermediaries between feeding and breeding would be useful. Moreover, a future study about the diet shift before the juvenile and adult state of $C$. guanes and other tropical fish would be necessary to know better the ontogenetic variations of diet in this fish.

Material Examined. Creagrutus guanes. All catalog numbers have the prefix UIS-T of the ichthyological collection of Universidad Industrial de Santander, Colombia. UIS-T 0024, 
0027, 0029, 0043, 0044, 0048, 0049, 0050, 0052, 0054, 0056, 0059, 0061, 0064, 0065, 0067, 0069, 0074, 0079, 0081, 0092, 0094, 0095, 0102, 0107, 0117, 0120, 0121, 0126, 0127, 0128, 0132, 0133, 0134, 0135, 0136, 0160, 0139, 0140, 0141, 0143, 0144, 0146, 0147, 0148, 0149, 0150, 0152, 0153, 0154, 0155, 0156, 0166, 0167, 0168, 0171, 0172, 0173, 0174, 0175, 0177, 0178, 0179, 0180, 0181, 0182, 0189, 0234, 0235, 0249, 0253, 0256, 0258, 0260, 0261, 0262, 0264, 0267, 0268, 0269, 0276, 0279, 0286, 0291, 0292, 0294, 0296, 0297, 0298, 1003, 1009, 1010, 1013, 1021, 1022, 1023, 1031, 1038, 1041, 1048,1049, 1050, 1051, 1052, 1053, 1054, 1055, 1056, 1057, 1058, 1059, 1060, 1061, 1062, 1092, 1106, 1107, 1126, 1127, 1130,1133, 1134, 1137, 1138, 1141, 1143, 1149, 1157, 1158, 1162, 1164, 1165, 1167, 1174, 1177, 1188, 1191, 1206, 1222, 1251, 1252, 1253, 1254, $1260,1261,1262,1263,1264,1265,1266,1271,1273,1274,1275$, $1276,1277,1278,1279,1280,1284,1288,1289,1292,1293,1295$, 1296, 1305, 1306, 1307, 1314, 1315, 1328, 1333, 1335, 1336, 1338, 1341, 1344, 1412, 1530, 1531, 1532, 1533, 1534, 1535, 1540, 1546, 1547, 1548, 1549, 1550, 1551, 1552, 1553, 1554,1555, 1556A, 1556B, 1557, 1558, 1559, 1560, 1561, 1563, 1564, 1565, 1570, $1571,1572,1574,1575,1576$.

\section{Acknowledgements}

Thanks to the Laboratorio de Biología Reproductiva de Vertebrados - Universidad Industrial de Santander and its members for the collaboration, important suggestions, and financial support. Jaime Mauricio Anaya made useful recommendations and gave support. Mercedes Valderrama and Víctor Hugo Serrano gave statistical advice. Mandy Bannet inspected the English. P. Sánchez and Eliete Silva who reviewed the Portuguese Language of the resumo. We are grateful to the Neotropical Ichthyology reviewers for suggestions and criticisms on this paper.

\section{Literature Cited}

Alkins-Koo, M. 2000. Reproductive timing of fishes in a tropical intermittent stream. Environmental Biology of Fishes, 57(1): 49-66.

Araújo, F. G., C. C. Andrade, R. N. Santos, A. F. G. N. Santos \& L. N. Santos. 2005. Spatial and seasonal changes in the diet of Oligosarcus hepsetus (Characiformes, Characidae) in a Brazilian reservoir. Brazilian Journal of Biology, 65(1): 1-8.

Balcome, S. R., S. E. Bunn, F. J. McKenzie-Smith \& P. M. Davies. 2005. Variability of fish diets between dry and flood periods in an arid zone floodplain river. Journal of Fish Biology, 67(6): 1552-1567.

Barreto, A. P. \& J. R. Aranha. 2006. Alimentação de quatro espécies de Characiformes de um riacho da Floresta Atlântica, Guaraqueçaba, Paraná, Brasil. Revista Brasileira de Zoologia, 23(3): 779-788.

Barros, S. E. 2004. Alimentación de Astyanax abramis (Characiformes: Characidae) en el Embalse Cabra Corral, Salta, Noroeste de Argentina. Revista AquaTIC, 20: 88-96.

Blanco-Parra, M. P. \& I. Bejarano-Rodríguez. 2006. Alimentación y reproducción de las principales especies ícticas del río Mesay durante el periodo de “aguas altas”. Revista de Biología Tropical, 54(3): 853-859.
Brooks, S., C. R. Tyler \& J. P. Sumpter. 1997. Egg quality in fish: what makes a good egg? Reviews in Fish Biology and Fisheries, 7(4): 387-416.

Castillo-Rivera, M., G. Moreno \& R. Iniestra. 1994. Spatial, seasonal, and diel variation in abundance of the bay anchovy, Anchoa mitchilli (Teleostei: Engraulidae), in a tropical coastal lagoon of Mexico. The Southwestern Naturalist, 39: 263-268.

Chapman, C. A. \& D. L. Kramer. 1991. Population dynamics of the fish Poecilia gilii (Poeciliidae) in pools of an intermittent tropical stream Lauren. Journal of Animal Ecology, 60: 441-453.

Clarke, K. R. 1993. Non-parametric multivariate analyses of changes in community structure. Australian Journal of Ecology, 18: 117143.

Clarke, K. R. \& R. M. Warwick. 1994. Change in Marine Communities. An Approach to Statistical Analysis and Interpretation. Plymouth, Plymouth Marine Laboratory, 144p.

Clarke, K. R. \& R. N. Gorley. 2001. PRIMER Version 5: user manual/tutorial. Plymouth, PRIMER-E, 99p.

De Alvarenga, E. R., N. Bazzoli, G. B. Santos \& E. Rizzo. 2006. Reproductive biology and feeding of Curimatella lepidura (Eigenmann \& Eigenmann) (Pisces, Curimatidae) in Juramento reservoir, Minas Gerais, Brazil. Revista Brasileira de Zoologia, 23(2): 314-322.

Esteves, K. E. \& P. M. Galleti Jr. 1995. Food partitioning among some characids of a small Brazilian floodplain lake from the Paraná River basin. Environmental Biology of Fishes, 42(4): 375-389.

Esteves, K. E. \& A. V. Pinto Lobo. 2001. Feeding pattern Salminus maxillosus (Pisces, Characidae) at Cachoeira Das Emas MogiGuaçu river São Paulo state, southeast Brazil). Revista Brasileira de Zoologia, 61(2): 267-276.

Friedman, J. M. \& G. T. Auble. 2000. Floods, flood control, and bottomland vegetation. Pp. 219-237. In: Wohl, E. (Ed.). Inland Flood Hazards: Human, Riparian and Aquatic Communities. Cambridge, Cambridge University Press, 498p.

Garman, G. C. 1991. Use of terrestrial arthropod prey by a streamdwelling cyprinid fish. Environmental Biology of Fishes, 30(3): 325-331.

González, P. \& C. Oyarzún. 2003. Diet of the chilean sandperch Pinguipes chilensis (Perciformes, Pinguipedidae) in southern Chile. Journal of Applied Ichthyology, 19(6): 371-375.

Goulding, M. 1980. The fish and the forest. Berkeley, University of California Press, 280p.

Hammer, Ø., D. A. T. Harper \& P. D. Ryan. 2001. PAST: Paleontological Statistics Software Package for Education and Data Analysis. Palaeontologia Electronica, 4(1): 1-9. Available from: http://palaeo-electronica.org/2001_1/past/issue1_01.htm

Humphries, P., A. King \& J. E. Koehnb. 1999. Fish, flows and flood plains: links between freshwater fishes and their environment in the Murray - Darling River system, Australia. Environmental Biology of Fishes, 56(1-2): 129-151.

Hurlbert, S. H. 1978. The measurement of niche overlap and some relatives. Ecology, 59(1): 67-77.

Ikomi, R. B. 1996. Studies on the growth pattern, feeding habits and reproductive characteristics of the mormyrid Brienomyrus longianalis (Boulenger 1901) in the upper Warri River, Nigeria. Fisheries Research, 26: 187-198.

Jiménez-Badillo, M. L. \& M. R. Nepita-Villanueva. 2000. Espectro trófico de la tilapia Oreochromis aureus (Perciformes: Cichlidae) en la presa Infiernillo, Michoacán-Guerrero, México. Revista de Biología Tropical, 48(2-3): 487-494.

Kramer, D. L. 1978. Reproductive seasonality in the fishes of a tropical stream. Ecology, 59(5): 976-985. 
Kramer, D. L. \& M. J. Bryant. 1995. Intestine length in the fishes of a tropical stream: 2. Relationships to diet: the long and short of a convoluted issue. Environmental Biology of Fishes, 42(2): 129-141.

Lake, J. S. 1967. Rearing experiments with five species of Australian freshwater fishes. I. Inducement to spawning. Australian Journal of Marine and Freshwater Research, 18(2): 155-176.

Lemus-Jiménez, L. J. \& N. Ramírez. 2002. Fenología reproductiva en tres tipos de vegetación de la planicie costera de la península de Paraguana, Venezuela. Acta Científica Venezolana, 53: 266-278.

Lytle, D. A. \& N. L. Poff. 2004. Adaptation to natural flow regimes. Trends in Ecology and Evolution, 19: 94-100.

Mazzoni, R. \& C. F. Rezende. 2003. Seasonal diet shift in a Tetragonopterinae (Osteichthyes, Characidae) from the Ubatiba river, RJ, Brazil. Brazilian Journal of Biology, 63(1): 69-74.

Mérigoux, S. \& D. Ponton. 1998. Body shape, diet and ontogenetic diet shifts in young fish of the Sinnamary River, French Guiana, South America. Journal of Fish Biology, 52: 556-569.

Munro, A. D. 1990. Tropical freshwater fishes. Pp. 145-239. In: Munro, A. D., A. P. Scott \& T. J. Lam (Eds.). Reproductive Seasonality in Teleosts: Environmental Influences. Boca Raton, CRC Press, 254p.

Ortaz, M. 1992. Hábitos alimenticios de los peces de un río de montaña neotropical. Biotropica, 24: 550-559.

Ortaz, M. 2001. Diet seasonality and food overlap in fishes of the upper Orituco stream, northern Venezuela. Revista de Biología Tropical, 49(1): 191-197.

Pinkas, L., M. S. Oliphant \& Y. L. K. Iverson. 1971. Food habits of albacore, bluefin tuna and bonito in Californian waters. Fish Bulletin, 152: 1-105.

Ponce-Calderón, M. E. 2002. Patrones de caída de frutos en Mauritia flexuosa L.F. y fauna involucrada en los procesos de remoción de semillas. Acta Botánica Venezuelica, 25(2): 119-142.

Prejs, A. \& K. Prejs. 1987. Feeding of tropical freshwater fishes: seasonality in resource availability and resource use. Oecologia, 71: 397-404.

Pusey, B. J., A. H. Arthington, P. G. Close \& J. R. Bird. 2002. Larval fishes in rainforest streams: recruitment and microhabitat use. Proceedings of the Royal Society of Queensland, 110: 27-46.

Ribeiro, V. M. A., G. B. Santos \& N. Bazzoli. 2007. Reproductive biology of Steindachnerina insculpta (Fernandez-Yépez) (Teleostei, Curimatidae) in Furnas reservoir, Minas Gerais. Brazil. Revista Brasileira de Zoologia, 24(1): 71-76.

Rinne, J. N. \& B. Wanjala. 1983. Maturity, fecundity, and breeding seasons of the major catfishes (Suborder Siluroidea) in Lake Victoria, East Africa. Journal of Fish Biology, 23: 357-363.

Román-Valencia, C. 1998. Alimentación y reproducción de Creagrutus brevipinnis (Pisces: Characidae) en Alto Cauca, Colombia. Revista de Biología Tropical, 46(3): 783-789.

Santamaría-Miranda, A., M. Saucedo-Lozano, M. N. Herrera-Moreno \& J. P. Apún-Molina. 2005. Hábitos alimenticios del pargo amarillo Lutjanus argentiventris y del pargo rojo Lutjanus colorado (pisces: Lutjanidae) en el norte de Sinaloa, México. Revista de Biología Marina y Oceanografía, 40: 33-44.

Schoener, T. 1970. Non-synchronous spatial overlap of lizards in patchy habits. Ecology, 51: 408-418.

Swanson, F. J., S. L. Johnson, S. V. Gregory \& S. A. Acker. 1998. Flood Disturbance in a Forested Mountain Landscape. BioScience, 48: 681-689.

Torres-Mejia, M. \& R. P. Vari. 2005. New species of Creagrutus (Teleostei: Characiformes: Characidae) from the Río Magdalena basin, Colombia. Copeia, 2005(4): 812-817.
Torres-Mejia, M. \& M. P. Ramírez-Pinilla. 2008. Dry-season breeding of a characin in a tropical mountain river. Copeia, 2008(1): 99-104.

Vazzoler, A. E. A. de M. \& N. A. Menezes. 1992. Síntese de conhecimento sobre o comportamento reprodutivo dos Characiformes da América do Sul (Teleostei: Characiformes). Revista Brasileira de Biologia, 52: 627-540.

Velásquez de Ríos, M., Z. Tiape, I. Goyareb \& R. Tamasaukas. 2004. Abundancia estacional de tabánidos (Diptera: Tabanidae) en el sector Las Lajas, Municipio Miranda, estado Guárico, Venezuela. Entomotropica, 19: 149-152.

Verhoeven, K. J. F., K. L. Simonsen \& L. M. McIntyre. 2005. Implementing false discovery rate control: increasing your power. Oikos, 108: 643-647.

Vilella, F. S., F. G. Becker \& S. M. Hartz. 2002. Diet of Astyanax species (Teleostei, Characidae) in an Atlantic Forest River in Southern Brazil. Brazilian Archives of Biology and Technology, 45(2): 223-232.

Wang, J. T., M. C. Liu \& L. S. Fang. 1995. The reproductive biology of an endemic cyprinid, Zacco pachycephalus, in Taiwan. Environmental Biology of Fishes, 43(2): 135-143.

Winemiller, K. O. 1990. Spatial and temporal variation in tropical fish networks. Ecological monographs, 60: 331-367.

Wootton, R. J. 1998. Ecology of Teleost Fishes. Dordrechth, Kluwer Academic Publishers, 386p.

Xie, S., Y. Cui, T. Zhang \& Z. Li. 2000. Seasonal patterns in feeding ecology of three small fishes in the Biandantang lake, China. Journal of Fish Biology, 57: 867-880.

Accepted August 18, 2009 Published December 18, 2009 